\title{
Exploring the roots and dynamics of Kurdish ethno-nationalism in Turkey
}

\author{
ZEKI SARIGIL and OMER FAZLIOGLU \\ Department of Political Science, Bilkent University, Ankara, Turkey
}

\begin{abstract}
Using comprehensive and original data derived from a recent major public opinion survey, this study examines an under-investigated aspect of the Kurdish issue in Turkey: the dynamics and factors behind Kurdish ethno-nationalism at a mass level. The empirical findings disprove the conventional socio-economic peace and Islamic-peace hypotheses around this issue, and our statistical analyses provide strong support for the relative deprivation hypothesis, i.e. that those who think the Turkish state discriminates against Kurds are more likely to have ethno-nationalist orientations. Multivariate analyses further show that religious sectarian differences among Kurds (i.e. the Hanefi-Shafi division) matter: the more religious Shafi Kurds have a stronger ethnic consciousness and a higher degree of ethno-nationalism. The study also provides a discussion of the broader theoretical and practical implications of the empirical findings, which may provide insights into conflict resolution prospects in countries with a Kurdish population.
\end{abstract}

KEYWORDS: Hanefi-Shafi division, Islamic peace, Kurdish ethno-nationalism, public opinion, relative deprivation, socio-economic peace

\section{Introduction}

The Kurdish issue, which has been a central problem in the Turkish Republic since its establishment in the early 1920s, has evolved into a major challenge in Turkey's domestic and external politics in the last decades. ${ }^{1}$ This study is primarily concerned with enhancing our empirical knowledge and understanding of the factors and dynamics behind ethno-nationalist attitudes among Turkey's Kurds. It also aims to contribute to the broader theoretical debate on ethno-nationalism and to provide some policy implications.

The existing literature provides a limited number of empirical works on Kurdish ethno-nationalism simply because state authoritarianism and repression prevented such research. ${ }^{2}$ Until the 1990s, the Turkish state simply ignored the existence of Kurdish ethnicity and the Kurdish problem in the country. Any public expression of Kurdish identity and demands was suppressed by the state (Barkey and Fuller 1998; Bozarslan 2001; Entessar 1992; Gunter 1990; Kirişçi and Winrow 1997; Romano 2006; Somer 2005; Tezcur 2009; Watts 1999). Although several Turkish politicians had acknowledged the existence of the 'Kurdish reality' in Turkey by the 1990s (see Gunter 1997: 
67; Kirişçi and Winrow 1997: 113), the state continued to consider the problem as issues of socio-economic underdevelopment (i.e. low level of income and education levels, and feudalism and tribalism in Kurdish areas) and terrorism rather than as an ethno-political issue (Bozarslan 1996; Sarigil 2009; Yegen 1996). Under the state of emergency that remained in force in several Kurdish provinces from 1987 till 2002, it was impossible to collect survey data on Kurdish demands.

By the 2000s, however, primarily due to European Union (EU) pressure and conditionality requirements, the state softened its repressive attitude and granted certain cultural rights to the Kurds. The liberalisation of Turkey's political environment also led to increasing scholarly research on various aspects of the Kurdish issue, but as most of the works focus on political elites (Turkish and/or Kurdish), they neglect the opinions and attitudes of the Kurdish masses. To explore that perspective, a growing number of public opinion surveys have emerged in the last decade, but many of them, mostly conducted by think thanks, suffer from major limitations and therefore fail to contribute to our comprehension of ethno-nationalist attitudes among Kurds. Most of the surveys are either politically motivated or do not conform to scholarly standards and requirements.

Given the urgent need for more comprehensive and objective empirical works on Kurdish public opinion, we conducted a major public opinion survey in late November 2011. The survey aimed to identify Kurdish demands and the possible factors (social, economic and political) shaping them. We believe that the empirical findings of this research not only contribute to our understanding of ethno-nationalism phenomena in general but also shed light on the debates of how to deal with the Kurdish issue. Now that the Turkish state acknowledges the problem and has been trying to accommodate Kurdish demands, we also believe our findings can help policy makers determine a peaceful solution.

With such motivations, this study broaches the following research questions: What do Kurds demand from the state? How strong are ethnonationalist orientations among Kurds? What factors hinder or promote Kurds' ethno-nationalist dispositions? How do social, economic and political factors and variables affect ethno-nationalist orientations among Kurds? (For instance, how does socio-economic status affect propensity towards ethnonationalism? Is a higher level of socio-economic status associated with a limited degree of ethno-nationalism? Does religiosity have a constraining impact on ethno-nationalist tendencies?) And finally, what theory and policy implications emerge from the findings?

Our statistical analyses show that the perception of discrimination is one of the strongest and most consistent determinants of ethno-nationalist orientation among Kurds. Those who think that the Turkish state discriminates against Kurds have a stronger degree of ethnic consciousness and are more likely to support cultural and political demands on the state. This finding provides strong support for the relative deprivation theory. Contrary to the 
Islamic-peace hypothesis, we find that religiosity does not really reduce or suppress ethno-nationalism. Socio-economic variables (e.g. income and education) also fail to have a consistent impact on ethno-nationalism among Kurds, disconfirming the socio-economic peace hypothesis. Ideology, region, unemployment and religious sect (Hanefi vs. Shafi) are other factors that shape Kurdish ethno-nationalism. Left-oriented and unemployed Kurds and those living in the southeast (Turkey's portion of the Kurd's historical homeland) are more likely to be supportive of ethno-nationalism. Another notable finding is that compared to Hanefi Kurds, the relatively more religious Shafi Kurds have a higher degree of ethnic consciousness and ethno-nationalist orientation. This finding suggests that religious sectarian differences also matter in Kurdish ethno-nationalism.

The article proceeds as follows: The next section discusses possible factors and variables that might account for Kurdish ethno-nationalism and derives some testable hypotheses. The section following provides data, variables and measurement. The empirical part presents our statistical analyses and results. The conclusion discusses the theoretical and practical implications of the empirical findings.

\section{Hypotheses}

The existing literature on ethno-nationalism in general and the Kurdish issue in particular draw attention to the role of a wide range of variables and factors (i.e. political, social, economic and demographic) in ethno-nationalist processes (e.g. see Barkey and Fuller 1998; Bozarslan 2001; Entessar 1992; Cornell 2001; Gunter 1990; Gurr 1970, 1993; Hechter 1975; Horowitz 1985; Icduygu et al. 1999; Kirişçi and Winrow 1997; Loizides 2010; McDowall 1996; Romano 2006; Rothschild 1981; Somer 2005; Tezcur 2009; Watts 1999; Yegen 1996, 2007). In this research, we are interested in exploring the possible impact of factors and variables related to socio-economic status, relative deprivation and religiosity on Kurdish ethno-nationalist orientations.

\section{Socio-economic approach (economic peace)}

This approach assumes that uneven development (i.e. socio-economic underdevelopment of a group or collectivity) provides favourable conditions for the emergence of ethno-nationalist or separatist orientations among the members of a disadvantaged group. Put differently, economic differentials are expected to foster ethno-nationalism. Icduygu et al. (1999), for instance, argue that a low level of socio-economic status will generate an environment of material and non-material insecurity which, in return, will facilitate ethnic revival and mobilisation. Likewise, Horowitz (1985: 233-9) suggests that separatist movements are more likely to be present among disadvantaged groups in economically underdeveloped regions (see also Entessar 1992; Hechter 1975; 
McDowall 1996: 402). Thus, the socio-economic approach treats ethnonationalism as a political reaction by socially and economically underprivileged groups or regions.

Such an approach has also dominated Turkish state's understanding of the Kurdish issue. Until the 2000s, the state ignored the ethno-political aspect of the Kurdish problem and framed it as a problem of socio-economic backwardness (i.e. feudalism, ignorance and poverty) and of terrorism and banditry (see Cornell 2001; Ergil 2000; Loizides 2010; Yegen 1996, 2007). As Yegen (1996) argues, the Turkish state discourse has been strikingly silent on the Kurdishness of the Kurdish question: 'Whenever the Kurdish question was mentioned in Turkish state discourse, it was in terms of reactionary politics, tribal resistance or regional backwardness, but never as an ethno-political question' (1996: 216). Similarly, Cornell (2001: 31-2) observes that the Turkish state believed that 'there [was] no Kurdish problem, but rather a socioeconomic problem in the southeastern region and a problem of terrorism that [was] dependent on external support from states aiming at weakening Turkey'. Aydinl (2002: 217) also notes that for the conventional understanding held by the state, '. . . eliminating poverty would eliminate the PKK [Partiya Karkaren Kurdistan, the Kurdistan Workers' Party], since the PKK's fighting ranks are peopled strictly by those with no economic alternatives'. Former Prime Minister Bülent Ecevit's (1999-2002) stance on the Kurdish issue well illustrates the socio-economic approach: 'Turkey does not have a Kurdish problem. There is socio-economic underdevelopment in the region. By abusing this, several external actors such as neighbouring and some European countries have promoted Kurdish terrorism/separatism in the region to destabilize and divide the Turkish Republic'. ${ }^{3}$

It is indeed the case that the southeastern region has been the least developed part of Turkey (see also Icduygu et al. 1999: 1002-6; Kiriş̧̧i and Winrow 1997; White 1998). Thus, many state and governmental officials assumed that this situation was the main reason behind Kurdish ethno-nationalism and separatism and that improving social and economic conditions there would constrain or suppress ethno-nationalist or separatist orientations. As a result, Turkish governments have implemented several economic packages and projects to invest in and allocate resources to the region to foster social and economic development (see Ergin 2000; Yegen 2011: 71). The state has also tried to encourage the private sector to invest in the area to decrease the high level of unemployment. ${ }^{4}$ It is expected that eradicating poverty through economic development programmes will eliminate mass support for the separatist, violent PKK and bring peace to southeastern Turkey.

The idea of peace through socio-economic development has also received strong support from intellectuals, writers and business circles. For instance, Gunes-Ayata and Ayata (2002: 143) maintain that 'socioeconomic development has a profound impact on ethnic identity and voting behaviour: It tends to reduce ethnonationalist sentiments and fosters more diversified political loyalties'. Similarly, columnist Dogan Heper states that 'It is a known fact that 
poverty always feeds terrorism ... If people start making money, then terror would decline. Therefore, we have to implement development programs to achieve industrialization and economic progress in the region'. 5 Thus, the economic-peace hypothesis would postulate that:

$\mathrm{H}_{1}$ : Individuals with high socio-economic status (i.e. a high level of income and education) would be less likely to have ethno-nationalist orientations.

\section{Relative deprivation approach}

The relative deprivation theory is also utilised in studies of ethno-nationalism. It is similar to the socio-economic approach but draws attention to the role of distinct dynamics and mechanisms in ethno-nationalist processes. Relative deprivation is defined as a perceived discrepancy between one's 'value expectations' and 'value capabilities'. The former refers to 'the goods and conditions of life to which people believe they are rightfully entitled', while the latter stands for 'the goods and conditions [people] think they are capable of attaining or maintaining, given the social means available to them' (Gurr 1970: 13). This approach asserts that as the perceived discrepancy or gap between the 'ought' and the 'is' increases, the intensity of discontent also increases. It is further argued that discontent, frustration or grievances due to unjust deprivation or differential treatment constitute one of the primary motivational forces of political action and/or ethnic mobilisation (e.g. violent or peaceful protest or rebellion) (see Gurr 1970, 1993). It is expected that 'the greater a group's relative disadvantage [e.g. political and economic differentials, poverty, discriminatory treatment] ... the greater the sense of grievance and, consequently, the greater its potential for political mobilization' (Gurr 1993: 174). In brief, frustration is likely to generate anger and aggression against the perceived source of frustration. This situation may benefit ethnic entrepreneurs because under the presence of discontent or frustration, it is relatively easier for political leaders to recruit members of a disadvantaged ethnic group.

It is important to emphasise that the relative deprivation theory draws attention to the 'perception' of deprivation. In other words, deprivation might be purely subjective. As Gurr (1970: 24) notes, ‘. . people may be subjectively deprived with reference to their expectations even though an objective observer might not judge them to be in want'.

One form of unjust deprivation or differential treatment is economic and/or political discrimination, which refers to 'patterned social behaviours by other groups (and the state) that systematically restrict group members' access to desirable economic resources and opportunities, and to political rights and positions' (Gurr 1993: 173). Discrimination creates discontent and grievances, which in turn feed aggression towards the state or dominant group.

Regarding the Kurdish case, almost half the Kurdish participants in our survey (47 per cent) think or perceive that the Turkish state discriminates against Kurds. Indeed, one might expect that frustration or discontent with the 
state's restrictions on Kurdish cultural and political rights would have promoted ethnic and political awareness among Kurds (see also Tezcur 2010: 778). As relative deprivation theory also expects, this situation is rather conducive to the rise of ethno-nationalist orientations. Thus, the frustrationaggression hypothesis provided by the relative deprivation theory anticipates that:

$\mathrm{H}_{2}$ : Members of an ethnic group perceiving discrimination by the state will be more likely to have an ethno-nationalist orientation.

\section{Pro-Islamic approach (Islamic peace)}

The role of religion is also discussed in debates on the Kurdish issue. As Ataman (2003) observes, according to the pro-Islamic approach, Islam does not reject different cultures and nationalities but attributes primary importance to overarching ideas and identities such as the 'Islamic brotherhood' and 'ummah' (the worldwide community of Muslim believers) rather than nationality or ethnicity (Ataman 2003; see also Cizre 1998: 81). Therefore, this approach regards Islam, which emphasises the unity of God and the unity of ummah, as incompatible with ethno-nationalist ideas and movements. The corollary of this view is that increasing religiosity and Islamic consciousness will weaken the role of ethnicity in self-identification and consequently constrain ethno-nationalist orientations. As Houston (2001: 157) observes:

... Islamist discourse on the Kurdish problem gives its assent to the existence and equality of Kurds as a kavim (people/nation) and to Kurdish as a language, but calls for the subordination of such an identity to an Islamic one ... Islamist discourse stakes a claim to be an ethnically neutral political actor: in the new social contract posited by Islamism, ethnic irons are withdrawn from the fire in the name of a more universalistic identity [ummah].

Such an understanding has also dominated conservative circles' approaches to the Kurdish issue in Turkey. ${ }^{6}$ The leadership of the ruling conservative Justice and Development Party (Adalet ve Kalkinma Partisi [AKP]), for instances, regards Islam as 'cement' between the Kurds and Turks and believes that the promotion of Islamic consciousness and the notion of the Islamic brotherhood should restrain ethno-nationalist or separatist tendencies (see also Yavuz and Ozcan 2006: 103-12). For instance, Bekir Bozdag, deputy prime minister responsible for Diyanet (the Directorate of Religious Affairs), ${ }^{7}$ states the following:

If a son of a Muslim husband and wife goes to the mountains and joins the terrorist organization [the PKK] to kill innocent people, it is because our men of religion do not really do their duty. If we could teach people Islam very well and if our officials, imams and Koran instructors do their duty appropriately, no terrorist organization would be able to recruit terrorists among the Muslims ... Thus, if there are still people joining the terrorist organization, it is partly because of the failure of our men of religion. ${ }^{8}$ 
Prime Minister Erdogan also frequently emphasises the notions of Islamic brotherhood and unity and tries to delegitimise Kurdish ethno-nationalists (i.e. the Peace and Democracy Party (Barıs ve Demokrasi Partisi, BDP) and the PKK) in the eyes of conservative Kurds by frequently claiming that they have nothing to do with Islam. On one occasion, Erdoğan addressed conservative Kurds as follows:

Those who perform namaz [salah] and those who say 'La ilahe illallah' [believing in and praying for only Allah] and those who have the love of Allah in their hearts cannot take sides with the terrorist organization. This land has a history shaped by ezan [adhan, the call to prayer], the Koran, and namaz. My religious, Muslim, Kurdish brother! When will you be aware of this conspiracy? You are the grandsons of Selahaddin Eyyubi and it is time for you to say 'Enough!' to this conspiracy. There cannot be any connection or relationship between you and the terrorist organization that does not pray to Allah or turn to the same qibla [the Caaba in Mecca, the holiest place of Islam] as you. ${ }^{9}$

As evident in the above statements, the leadership of the ruling conservative party treats Kurdish ethno-nationalists as un-Islamic and thus illegitimate. For the AKP leadership, Islam is a unifying bond between the Kurds and Turks. It provides a supra-identity, transcending tribal, ethnic and national identities. Thus, assuming that Islam and ethno-nationalism are incompatible, the AKP leadership expects that emphasising and promoting Islam and Islamic values among the Kurds would reduce support for ethno-nationalism and separatism in the region.

Such an approach is shared by several circles outside politics (e.g. academia and media). For instance, treating Islam as a peacemaker, Mitchell (2012) asserts that 'Political Islam may not solve all of Turkey's worries, but in the case of Kurds it seems to have [bridged] some of the gaps'. Similarly, Yavuz (1998: 12) notes that ' . . . the Islamic layer of identity could be useful in terms of containing ethnic tensions and finding a peaceful solution'. Yildiz (2012) asserts that '[a] Muslim individual who is after Allah's goodwill and consent cannot kill anyone ... A terrorist cannot be a Muslim, a Muslim cannot be a terrorist ... The spirit of brotherhood [between Turks and Kurds] can be revived only through religion [Islam]'. Finally, columnist Aslan (2012) contends that '[a]dherence to Islam usually softens ethnic conflicts'. Given all the above, the Islamic-peace hypothesis expects that:

$\mathrm{H}_{3}$ : As religiosity increases, the likelihood of ethno-nationalist orientation decreases.

In the scholarly literature, we see two empirical tests of the above hypothesis, and with conflicting results: Sarigil (2010) finds that religiosity does not have a statistically significant impact on ethno-nationalist orientations. Ekmekci (2011), however, argues that Islam does have a constraining impact on Kurdish ethno-nationalism. Both analyses are limited because they rely on the World Values Survey data set, which is not really designed to understand the societal dynamics behind Kurdish ethno-nationalism. In this study, we test 
the above hypothesis by using an improved data set, specifically designed to uncover factors and dynamics shaping ethno-nationalist orientations among Turkey's Kurds.

\section{Data, variables and measurement}

To test the hypotheses outlined above, we use original data based on a comprehensive public opinion survey, which was conducted in late November 2011 with a nationally representative sample. In designing the survey, we collaborated with $A \& G$, a professional public opinion research company based in Istanbul. ${ }^{10}$ The survey was implemented by experienced $A \& G$ researchers through face-to-face interviews with 6,516 respondents, aged 18 or older, from seven regions, 48 provinces and 186 districts. The sample was drawn through multistage, stratified cluster-sampling procedures. ${ }^{11}$ Age and gender quotas were also applied. In terms of ethnicity, 14 per cent of respondents in the sample identify themselves as ethnic Kurds (i.e. 901 individuals). The statistical analyses below are based on the data provided by the Kurdish sub-sample.

As this research is primarily concerned with investigating factors and dynamics behind ethno-nationalist dispositions or orientations among Turkey's Kurds, the dependent variable is ethno-nationalism at a mass level. It is quite a challenging task, however, to define and measure ethno-nationalism. Benefiting from various conceptualisations in the existing literature, ${ }^{12}$ we define 'ethnonationalist orientation' as 'sympathy and support for a disadvantaged ethnic group's demands for more political, economic and cultural rights and interests'. Because ethnic demands might range from the recognition of ethnic differences and basic linguistic and cultural rights to relatively more extreme claims such as statehood or total separation, ethno-nationalism should be understood as a matter of degree. Further, some members of a subordinated ethnic group might have more moderate demands, while others might support more extreme demands. For instance, the majority of Kurdish respondents in our survey (70-85 per cent) want more cultural rights (e.g. language rights), but they are less supportive ( 24 per cent) of total independence. Thus, it would be more appropriate to treat ethno-nationalism as a continuous variable rather than a dichotomous one.

To measure ethno-nationalism more precisely, we constructed two additive indices using factor analyses. Table 1 presents the results of our principal component factor analyses with varimax rotated solutions. As evident, various Kurdish demands can be aggregated into two different factors or dimensions: cultural (linguistic) and political. ${ }^{13}$ Variables related to linguistic demands load best on the first factor, which we call cultural ethno-nationalism. We added those variables to form an additive index for the first dimension (i.e. the cultural dimension of ethno-nationalism). Relatively more political and radical demands (i.e. Kurdish as an official language, regional flag, regional assembly and total separation) have relatively higher loadings on the second 
Table 1. Factor analysis of Kurdish demands

\begin{tabular}{lcc}
\hline \hline \multirow{2}{*}{ Variables } & \multicolumn{2}{c}{ Factor loadings } \\
\cline { 2 - 3 } & $\begin{array}{c}\text { Cultural ethno- } \\
\text { nationalism }\end{array}$ & $\begin{array}{c}\text { Political ethno- } \\
\text { nationalism }\end{array}$ \\
\hline Regional flag & 0.249 & 0.865 \\
Regional assembly & 0.256 & 0.824 \\
Kurdish as official language & 0.370 & 0.734 \\
Independent Kurdish state & 0.085 & 0.762 \\
Education in mother language & 0.654 & 0.428 \\
Place names in Kurdish & 0.802 & 0.283 \\
Kurdish sermons & 0.775 & 0.268 \\
Elective Kurdish courses & 0.778 & 0.063 \\
\% of variance & 32.12 & 36.07 \\
\hline \hline
\end{tabular}

Notes:

N: 901.

Extraction method: Principal component analysis.

Rotation method: Varimax with Kaiser Normalisation.

Rotation converged in three iterations.

factor or dimension, which we label 'political ethnonationalism'. Similarly, we aggregated those variables to form an index for the relatively more political dimension of ethno-nationalism. Together, these two dimensions capture 68 per cent of the variation in the set of variables included in the factor analyses. In brief, it would be more appropriate to treat these dimensions as two separate dependent variables.

In measuring independent variables, we also employed responses to the relevant items in the questionnaire (see Appendix B for the operationalisation of all variables). As indicators of socio-economic status, we used income and education levels. Regarding the perception of discrimination, we used participants' responses to the following survey question: 'In your opinion, do you think that the state discriminates against Kurds?'

Similar to ethno-nationalism, religiosity is also a complex notion and difficult to measure. As previous analyses show, it might have multiple dimensions such as faith, practice and attitude (e.g. see Carkoglu and Kalaycioglu 2009). Thus, we also conducted factor analyses to identify possible dimensions of religiosity. We selected the items with the highest factor loadings and then combined them to form two additive indices, capturing the practical and attitudinal dimensions of religiosity (see Appendix B).

Table 2 and Table 5 below provide regression analyses of cultural and political dimensions of ethno-nationalism among Kurds. Because the dependent variables are categorical and ordered (see Appendix A for descriptive statistics), we used an ordered logistical regression with robust standard errors. ${ }^{14}$ While testing the above hypotheses, we also control for the possible 
Table 2. Ordinal-logit regression analysis of 'cultural ethno-nationalism' among Kurds.

\begin{tabular}{|c|c|c|}
\hline & \multicolumn{2}{|c|}{ Dependent variable: Cultural ethno-nationalism } \\
\hline & Model 1 & Model 2 \\
\hline \multicolumn{3}{|l|}{ Predictors } \\
\hline Income (logged) & $-0.1986435(0.3038979)$ & $0.0508035(0.3844399)$ \\
\hline Education & $-0.1360174(0.0550287)^{*}$ & $-0.2280578(0.0678848)^{* *}$ \\
\hline $\begin{array}{l}\text { Discrimination } \\
\text { perception }\end{array}$ & $1.715048(0.1462555) * * *$ & $1.083378(0.1805336)^{* * *}$ \\
\hline $\begin{array}{l}\text { Religiosity index } \\
\text { (practice) }\end{array}$ & $-0.0328585(0.1074432)$ & $-0.0070554(0.1324503)$ \\
\hline $\begin{array}{l}\text { Religiosity index } \\
\text { (attitude) }\end{array}$ & $0.2504553(0.122724)^{*}$ & $0.1182366(0.1527491)$ \\
\hline \multicolumn{3}{|l|}{ Control variables } \\
\hline Ideology (left-right) & & $-0.7158616(0.1070086)^{* * *}$ \\
\hline Residence (rural-urban) & & $0.0937092(0.105733)$ \\
\hline Region (southeast) & & $0.8852116(0.1799141)^{* * *}$ \\
\hline Unemployment & & $0.8675502(0.2961336)^{* *}$ \\
\hline Religious sect (Shafi) & & $0.9738835(0.1695052)^{* * *}$ \\
\hline Gender & & $-0.0711921(0.1688917)$ \\
\hline Age & & $-0.0108354(0.0068269)$ \\
\hline$\tau_{1}$ & $-0.0462871(1.060834)$ & $-3.019259(1.508219)$ \\
\hline$\tau_{2}$ & $0.8156665(1.063479)$ & $-1.973655(1.501008)$ \\
\hline$\tau_{3}$ & $1.509857(1.063673)$ & $-1.06563(1.499415)$ \\
\hline$\tau_{4}$ & $2.226735(1.068623)$ & $-0.2072825(1.508471)$ \\
\hline $\mathrm{N}$ & 752 & 692 \\
\hline Pseudo $R^{2}$ & 0.0725 & 0.1655 \\
\hline Log pse. likelihood & -948.52868 & -787.19631 \\
\hline Wald $\chi^{2}(5) /(12)$ & 143.99 & 251.55 \\
\hline Prob $>\chi^{2}$ & 0.0000 & 0.0000 \\
\hline
\end{tabular}

Notes: $* \mathrm{p}<0.05, * * \mathrm{p}<0.01, * * * \mathrm{p}<0.001$.

Robust standard errors are in parentheses. Stata 12 is used in statistical analysis. Stata 12, StataCorp, College Station, Texas, USA.

impact of ideology, religious sect, gender, age, region and rural-urban distinction.

\section{Results}

Model 1 in Table 2 shows that income does not really matter in terms of cultural ethno-nationalism but that more education is likely to reduce cultural ethno-nationalism. These empirical findings provide only partial support for the socio-economic peace hypothesis. The perception of discrimination, on the other hand, has a strong impact on cultural ethno-nationalism: Kurds who 
Table 3. Contingency table of religious sect (mazhab) and voting preferences of Kurds.

\begin{tabular}{cccccccc}
\hline \hline & & \multicolumn{5}{c}{ Religious sect } & \\
\cline { 3 - 7 } & & Hanefi & Shafi & Alevi & Shia-Caferi & Other & Total \\
\hline Voting & Other & 67 & 83 & 11 & 0 & 4 & 165 \\
preference & Parties & $20.5 \%$ & $16.9 \%$ & $40.7 \%$ & $0 \%$ & $30.7 \%$ & $19.2 \%$ \\
& BDP & 79 & 291 & 15 & 1 & 9 & 395 \\
& & $24.2 \%$ & $59.3 \%$ & $55.5 \%$ & $100 \%$ & $69.2 \%$ & $46 \%$ \\
& AKP & 180 & 117 & 1 & 0 & 0 & 298 \\
\multirow{2}{*}{ Total } & $55.2 \%$ & $23.8 \%$ & $3.7 \%$ & $0 \%$ & $0 \%$ & $34.7 \%$ \\
& & 326 & 491 & 27 & 1 & 13 & 858 \\
\hline \hline
\end{tabular}

$\chi^{2}: 223.191 ;$ df: $28 ; \mathrm{p}<0.001$.

think they face discrimination (e.g. political, economic or cultural) are more likely to develop an ethno-nationalist orientation. This finding provides strong support for the grievance hypothesis provided by the relative deprivation theory. The Islamic-peace hypothesis, however, is not really confirmed. Contrary to expectations, the attitudinal dimension of religiosity has some positive impact on cultural ethno-nationalism.

The average effects of the variables of interest on cultural ethnonationalism do not change much when we control for various other factors in Model 2. As shown, attitudinal religiosity becomes insignificant. The second model further shows that ideological orientation, region, unemployment and religious sect matter. Moving from left to right, we see that the likelihood of ethno-nationalist orientation declines. In other words, left-oriented Kurds are more likely to be supportive of cultural demands. This finding is probably a result of the leftist legacy of the Kurdish nationalist movement. It is well known that the Kurdish movement (both its peaceful and violent versions) is rooted within the leftist movement (see Jongerden and Akkaya 2011). Kurds from the southeastern part of Turkey are more likely to have an ethnonationalist orientation compared to Kurds living in other regions. This finding suggests that the concentration of Kurds in the southeast, also referred to as the Kurds' 'ethnic homeland', appears to have a stronger ethnic consciousness and solidarity than Kurds do in other regions. Unemployment also promotes cultural ethno-nationalism, which might be linked to the deprivationfrustration hypothesis.

Finally, it is quite striking that compared to Hanefi Kurds, Shafi Kurds are more likely to be culturally ethno-nationalist. This outcome is not what we expected because the Hanefi and Shafi schools of Sunni Islam are assumed to be quite similar in terms of belief systems. ${ }^{15}$ However, the Hanefi-Shafi division among Kurds seems to have major political implications. Table 3 provides 
Table 4. Contingency table of religious sect (mazhab) and discrimination perception

\begin{tabular}{cccccccc} 
& & \multicolumn{6}{c}{ Religious sect } \\
\cline { 2 - 6 } & & Hanefi & Shafi & Alevi & Shia-Caferi & Other & Total \\
\hline Discrimination & No & 230 & 216 & 12 & 0 & 3 & 461 \\
perception & & $69.7 \%$ & $43.9 \%$ & $44.4 \%$ & $.0 \%$ & $21.4 \%$ & $53.3 \%$ \\
& Yes & 100 & 276 & 15 & 2 & 11 & 404 \\
& & $30.3 \%$ & $56.1 \%$ & $55.6 \%$ & $100.0 \%$ & $78.6 \%$ & $46.7 \%$ \\
& Total & 330 & 492 & 27 & 2 & 14 & 865 \\
& & $100.0 \%$ & $100.0 \%$ & $100.0 \%$ & $100.0 \%$ & $100.0 \%$ & $100.0 \%$
\end{tabular}

$\chi^{2}: 61.947 ; \mathrm{df}: 4 ; \mathrm{p}<0.001$.

further evidence for the different political orientations among these two religious sects. It shows that Shafi Kurds, who are relatively more religious, are more likely to vote for the ethno-nationalist BDP, while Hanefi Kurds prefer the conservative AKP.

Another interesting difference between these two groups is related to discrimination perception. As Table 4 shows, compared to Hanefi Kurds, many more Shafi Kurds think that the state has been discriminating against Kurds (30 per cent and 56 per cent, respectively). Put differently, discrimination perception is much stronger among Shafi Kurds. The state's promotion of Hanefi understanding through Diyanet and public education is probably one source of the relatively stronger discrimination perception among Shafi Kurds.

These statistical findings provide enough evidence to conclude that the religious sectarian division (i.e. the Hanefi-Shafi division) among Kurds has major political consequences. Why would this be? Our further research and contemplation show that the Hanefi school is the dominant Islamic jurisprudence among Turks. It was also the official law school of the Ottoman-Turkish state (Bruinessen 2000: 47). Kurds, on the other hand, have traditionally practiced the Shafi school of Sunni Islam, but due to interaction with Hanefi Turks through time, many Kurds converted to the Hanefi understanding. ${ }^{16}$ McDowall (1996: 432-3) observes that the Hanefi school emphasises the duty of obedience to state authority, while the Shafi school is less deferential to authority. ${ }^{17}$ Furthermore, it is believed that Shafi Kurds, who have been relatively more rural and peripheral, have remained distant from the central authority, while the more urban Hanefi Kurds have become more integrated into the political system. ${ }^{18}$ As a result of this factor, we see a striking difference between Hanefi and Shafi Kurds' attitudes towards the state. Such differences persisted during the Republican period primarily because, similar to Ottoman state, the Republican state adopted the Hanefi understanding as the official school of Islamic jurisprudence and promoted Hanefi teachings and understandings through Diyanet and public education (Smith 2005). Some experts 
observe that despite its minor differences from the Hanefi school, the Shafi school has been an important constituent element of Kurdish identity. For instance, Bruinessen (2000: 15), a prominent Kurdologist, states that

[m] ost of [Turkey's Kurds] follow the Shafi'i mazhab (school of Islamic jurisprudence), which distinguishes them from their Turkish and Arab Sunni neighbors, who generally follow the Hanafi school. To some Kurds therefore the Shafi'i mazhab has become one of the outward signs by which they assert their ethnic identity.

This empirical finding has further implications. The existing studies explain the popularity of conservative parties among Kurds by drawing attention to their anti-system and Islamic nature. Barkey (1998: 132), for instance, states that 'the Kurds have gravitated towards the Islamists because they have, in the past, perceived Welfare [a pro-Islamic party, 1983-1998] as the most antisystem party'. Similarly, Yavuz and Ozcan (2006: 109) note that 'most of the JDP's [AKP's] votes came from Islamically influenced Kurdish villages, towns and cities. Those Kurds whose views were shaped by the Nakshbandi and Nurcu religious networks supported the JDP because it was against the "system"'. Whether the AKP is a pro- or anti-system party is an aside, but our findings show that Hanefi Kurds, who are regarded as relatively more integrated into the political system, are more likely to support the ruling, conservative AKP and the relatively more religious and peripheral Shafi Kurds are more likely to endorse ethno-nationalist ideas and formations (see Table 3).

Table 5 presents an ordinal-logit regression analysis of political ethnonationalism. The first model shows that income and education do not have a statistically significant impact on the level of political demands. Similar to cultural demands, discrimination perception has a positive and statistically significant impact on political ethno-nationalism. This relationship also holds in the second model, which controls for several other factors and provides a better specification. The practical dimension of religiosity seems to reduce the likelihood of political ethno-nationalism in both models, but the attitudinal dimension remains irrelevant. Overall, these findings support the relative deprivation hypothesis but question the assumptions of the socio-economic and Islamic-peace hypotheses.

Regarding control variables, ideology makes a difference. Compared to right-oriented individuals, left-oriented individuals are more likely to support more extreme demands. We see a similar attitude among young individuals; younger generations appear to be more receptive to a more radical form of ethno-nationalism. Residential and regional differences also matter. Kurds living in urban centres and in southeastern Turkey are more likely to support political ethno-nationalism. There might be multiple reasons behind this outcome, one being forced migration from rural to urban areas. During the armed conflict between Turkish security forces and the PKK in the late 1980s and the 1990s, the state evacuated about 3200 villages in eastern and southeastern Anatolia, forcing a significant number of Kurds to migrate to the cities. ${ }^{19}$ This forced migration seems to have reinforced an ethnic 
Table 5. Ordinal-logit regression analysis of 'political ethno-nationalism' among Kurds

\begin{tabular}{|c|c|c|}
\hline & \multicolumn{2}{|c|}{ Dependent variable: 'Political ethno-nationalism' } \\
\hline & Model 1 & Model 2 \\
\hline \multicolumn{3}{|l|}{ Predictors } \\
\hline Income (logged) & $-0.3161454(0.2743707)$ & $-0.2394461(0.278866)$ \\
\hline Education & $0.013944(0.0495233)$ & $-0.1269213(0.0653555)$ \\
\hline Discrimination perception & $2.399424(0.1647682)^{* * *}$ & $1.858068(0.1943057)^{* * *}$ \\
\hline Religiosity index (practice) & $-0.321358(0.1019862)^{* *}$ & $-0.2466117(0.1173847)^{*}$ \\
\hline Religiosity index (attitude) & $0.0255832(0.1084418)$ & $0.0154935(0.1470632)$ \\
\hline \multicolumn{3}{|l|}{ Control variables } \\
\hline Ideology (left-right) & & $-0.7823593(0.1090208)^{* * *}$ \\
\hline Residence (rural-urban) & & $0.2806193(0.107721)^{* *}$ \\
\hline Region (southeast) & & $0.8557438(0.1675667)^{* * *}$ \\
\hline Unemployment & & $0.5608334(0.2969214)$ \\
\hline Religious sect (Shafi) & & $0.0404736(0.1743428)$ \\
\hline Gender & & $0.1553978(0.1589467)$ \\
\hline Age & & $-0.0130042(0.0065111)^{*}$ \\
\hline$\tau_{1}$ & $1.0273(0.9668972)$ & $-1.566185(1.274879)$ \\
\hline$\tau_{2}$ & $1.983515(0.9676383)$ & $-0.441865(1.275613)$ \\
\hline$\tau_{3}$ & $2.529474(0.9721195)$ & $0.2059868(1.275822)$ \\
\hline$\tau_{4}$ & $3.551029(.9788709)$ & $1.290961(1.277361)$ \\
\hline $\mathrm{N}$ & 749 & 691 \\
\hline Pseudo $R^{2}$ & 0.1283 & 0.1932 \\
\hline Log pse. likelihood & -974.52037 & -825.88148 \\
\hline Wald $\chi^{2}(5) /(12)$ & 227.03 & 367.67 \\
\hline Prob $>\chi^{2}$ & 0.0000 & 0.0000 \\
\hline
\end{tabular}

Notes: ${ }^{*} \mathrm{p}<0.05, * * \mathrm{p}<0.01, * * * \mathrm{p}<0.001$.

Robust standard errors are in parentheses. Stata 12 is used in statistical analysis.

consciousness among internally displaced Kurds, paving the way for relatively stronger support of political ethno-nationalism. Urban centres also provide a more conducive setting than rural areas for organising and spreading ethno-nationalist ideas and movements. Finally, unemployment, religious sect and gender make no difference in terms of supporting more political ethnic demands.

\section{Implications}

Our findings have several implications. First, they imply that socio-economic improvements may not necessarily suppress or constrain ethno-nationalist orientations among Turkey's Kurds. As McGarry (1995: 137) also observes, 
'... [e]conomic growth alone, without a political settlement which seeks to address the political aspirations of the warring ethnonational groups, will have little effect upon ethnonational conflict'. The Kurdish case provides strong support for this observation. Ethno-national tensions and conflicts are also present among advanced, modern regions (e.g. Quebec in Canada; the Basque and Catalan cases in Spain) (see also Gurr 1993: 82; Hale 2000; Sorens 2005).

Regarding the nexus between Islam and nationalism, as indicated above, several pro-Islamic circles treat religion and ethno-nationalism as mutually exclusive and thus expect that increases in religiosity would suppress or constrain ethno-nationalist orientations. However, our empirical findings imply that the policy of promoting Islamic values and consciousness to suppress Kurdish ethno-nationalism would not really produce the desired outcome.

Another issue concerning the role of religion in ethno-nationalism is the argument that asserts religious differences (e.g. Alevi-Sunni division) should cross-cut ethnic differences (Turkish and Kurdish) and prevent further tension and conflict between these two communities. For instance, Kocher (2002: 138) states:

There is a key religious distinction that directly crosscuts the Kurdish/Turkish cleavage. Although the majority of the residents of Anatolia are Sunni Muslims, as many as 30 per cent are members of religious groups that are historically and doctrinally related to Shi'ism. By far the largest of these groups is the Alevi, and this name is often used as shorthand for all Shi'ite-derived groups within Turkey. Roughly an equal proportion of Kurds and Turks are Alevi.

It is believed that the cross-cutting Alevi-Sunni divide facilitates rapprochement between Turks and Kurds and alleviates possible tensions. It is, for instance, suggested that intermarriage between Sunni Turks and Kurds is more common than intermarriage between Sunnis and Alevis (Kocher 2002: 139).

The Alevi-Sunni cleavage might indeed cross-cut the Turkish-Kurdish ethnic division but our empirical findings above indicate that there is also a separate sectarian division among Kurds, with major political implications: the Hanefi-Shafi division among Sunni Kurds. Rather than cross-cutting the ethnic division, however, it actually overlaps or coincides with the TurkishKurdish division. ${ }^{20}$ Although the Alevi-Sunni divide and its implications for political behaviour are already addressed in the literature (e.g. see Carkoglu 2005; Gunes-Ayata and Ayata 2002), we do not know much about the sources and political implications of the Hanefi-Shafi division among Kurds. Therefore, more research on the sources of religious sectarian division within the Kurdish population and its implications for the Kurdish ethno-nationalist movement would be worthwhile.

Finally, one of the study's most robust empirical findings is that the perception of discrimination creates a favourable environment for cultural and political ethno-nationalism alike. Kurds who think that the state discriminates against them are more likely to have an ethno-nationalist orientation. And, as 
indicated above, almost half of the Kurds surveyed feel and perceive that the state discriminates against them. This finding suggests that the state should take further steps in political, economic and cultural realms to eliminate or reduce such perceptions among Kurds. To be fair, in the last decade Turkish governments have already achieved major institutional and legal reforms, which have enhanced the Kurds' cultural rights. After the EU granted Turkey candidacy status during the Helsinki Summit in 1999, Turkey faced EU requirements to improve Kurdish rights and freedoms. For instance, Turkish governments have legalised publishing and broadcasting in Kurdish and learning the Kurdish language, permitted parents to give their children Kurdish names, allowed political party campaigns in Kurdish, opened Institutes of Kurdology at some public universities, introduced elective Kurdish courses for secondary level public schools and allowed defence in Kurdish during court trials. Such changes are extremely important, given that until the 1990s the state denied even the Kurds' existence in Turkey. However, there are still several restrictions on Kurdish identity and rights, such as a ban on education in mother language, a 10 per cent electoral threshold (a major barrier in front of Kurdish political representation) and an exclusionary notion of citizenship based on Turkishness. Such persisting restrictions also promote the apparent still-existing discrimination perception among Kurds, particularly among Shafi Kurds. Therefore, there remains need for further reform and change. From that perspective, the enactment of a new constitution, which recognises and guarantees Kurdish identity and rights, might help the state win hearts and minds of the Kurds.

\section{Acknowledgements}

We would like to thank Levent Duman, Gunes Ertan, Emanuele Massetti, Yalcin Murgul, Elisabeth Ozdalga, Nil S. Satana, Ali Tekin and Mesut Yegen for their valuable comments and suggestions.

\section{Funding}

The data that this article uses comes from a research project, which was fully funded by the Economic Policy Research Foundation of Turkey (TEPAV).

\section{Notes}

1 For further discussion on various aspects of the Kurdish issue in Turkey, see Barkey and Fuller (1998); Bozarslan (2001); Bruinessen (1992, 2000); Casier and Jongerden (2011); Entessar (1992); Gunter (1990, 1997); Heper (2007); Jwaideh (2006); Kirişçi and Winrow (1997); McDowall (1996); Olson (1996); Ozkirimli (2013); Romano (2006); Saatci (2002); Somer (2005); Watts (1999); White (2000); Yavuz (2001); Yegen (1996, 2007, 2011). 
2 For a few notable empirical works, see Icduygu, Romano and Sirkeci (1999); Sarigil (2010).

3 Quoted in Sarigil (2010: 538).

4 See, for instance, 'Doğu'da yatırım yapan Batı'da vergiden düşecek'. Milliyet, 6 April 2012. http://ekonomi.milliyet.com.tr/dogu-da-yatirim-yapan-bati-da-vergiden-dusecek/ekonomi/ ekonomidetay/06.04.2012/1524613/default.htm. Accessed on 25 August 2012; 'Teşvik paketi, Güneydogu'ya yatırıma ilgiyi artırdı'. Hürriyet, 17 April 2012. http://www.hurriyet.com.tr/ ekonomi/20362623.asp. Accessed on 25 August 2012.

5 'PKK bitti, şimdi yatırım zamanı'. Milliyet, 17 February 2000. http://www.milliyet.com.tr/ 2000/02/17/yazar/heper.html. Accessed on 26 August 2012.

6 For some examples of studies analysing pro-Islamic circles' positions on the Kurdish issue, see Cizre (1998); Duran (1998); Houston (1999, 2001).

7 Diyanet is a state institution that oversees religion and religious services. It was established in 1924 and controls nearly 80,000 mosques in Turkey. Because Diyanet is based on Hanefi-Sunni Islam (see Smith 2005), it is criticised particularly by Shafi Kurds and Alevis (Turkish and Kurdish). These groups are also critical of religion classes in public schools. They argue that the state promotes Hanefi teachings, excluding or neglecting Alevi and Shafi teachings.

8 'Din adamlarimizin hatasi var'. Haber Türk, 21 January 2012. http://www.haberturk.com/ gundem/haber/708246-din-adamlarimizin-hatasi-var. Accessed on 27 August 2012.

9 'La ilahe illallah diyen, terör örgütüyle aynı yere bakamaz'. Haber Türk, 6 December 2012, http://www.haberturk.com/gundem/haber/800731-la-ilahe-illallah-diyen-teror-orgutuyle-ayniyere-bakamaz. Accessed on 9 December 2012.

10 While working on the initial form of questionnaire, we benefited from the existing literature on various debates around Turkey's Kurdish issue and also from our interviews with experts on the Kurdish issue and Kurdish activists based in Diyarbakir, Ankara and Istanbul. Next, we organised several meetings and workshops with $A \& G$ representatives and researchers in Ankara to work on the survey. We finally drafted the survey in early 2011 . To identify possible problems with the draft survey, we conducted and participated in pilots in late February 2011 in Istanbul, Ankara, Malatya, Mersin and Diyarbakir. Based on feedback from the pilots and further suggestions by experts, we revised the draft survey. Before implementing the final version of the survey, we invited all regional heads of $A \& G$ to attend a half-day workshop in Ankara in mid-November to familiarise them with the survey.

11 The following provinces are included in the sample: Adana, Adiyaman, Afyon, Agr1, Amasya, Ankara, Antalya, Aydın, Balikesir, Batman, Bingol, Burdur, Bursa, Cankiri, Corum, Denizli, Diyarbakir, Elazig, Edirne, Erzurum, Eskisehir, Gaziantep, Giresun, Hatay, Isparta, Icel, Istanbul, Izmir, Kayseri, Kirklareli, Kocaeli, Konya, Malatya, Manisa, Maras, Mardin, Mus, Nigde, Ordu, Osmaniye, Rize, Sakarya, Samsun, Sivas, Trabzon, Sanliurfa, Usak ve Zonguldak.

12 For instance, Connor (1994: XI) argues that ethno-nationalism is not really different than nationalism, which he defines as identification with and loyalty to one's nation, nation itself referring to 'a group of people who believe they are ancestrally related'. However, he distinguishes between an ethnic group and a nation (1994: 103). Members of an ethnic group are not aware of the group's uniqueness. Once they have such awareness, the group becomes a nation. Thus, Connor regards an ethnic group as a potential nation. Rothschild (1981: 6) defines ethno-politics or ethno-nationalism as 'the politicization of ethnicity', which translates 'the personal quest for meaning and belonging into a group demand for respect and power'. The terms 'ethnicity' and 'ethnic' for Rothschild (1981: 9) refer to 'the political activities of complex collective groups whose membership is largely determined by real or putative ancestral inherited ties, and who perceive these ties as systematically affecting their place and fate in the political and socioeconomic structures of their state and society'. For Lecours (2000: 105), ethno-nationalism is 'the action of a group that claims some degree of self-government on the grounds that it is united by a special sense of solidarity emanating from one or more shared features and therefore forms a "nation", Conversi (2000: 6) defines ethno-nationalism as 'movements acting on behalf of stateless nations'. 13 The eigenvalues and the scree plot also confirm that two factors can be extracted from the set of variables. 
14 For more discussion on this technique, see Long (1997) and Menard (2002).

15 Sunni Islam recognises four schools of law or jurisprudence (figh): Hanefi, Shafi, Maliki and Hanbali. In Turkey, the Hanefi and Shafi schools are the most common and their differences seem to be more related to rituals. For instance, Shafis perform morning prayer earlier and they hold their hands in a different position during prayer. They also have different rules for what disturbs ritual purity (see Bruinessen 2000: 15). Prof. Dr. Ahmet Erkol from the Faculty of Divinity at Dicle University cited the same differences during an interview with the authors (Diyarbakir, 19 February 2012).

16 In contemporary Turkey, Hanefi Kurds constitute around 35 per cent of the Kurdish population.

17 We believe that this striking difference deserves separate research.

18 Authors' interview with Prof. Dr. Ahmet Erkol.

19 Many Kurds also left their villages due to PKK pressure or insecurity resulting from the fighting between state security forces and the PKK. Estimations of the number of internally displaced Kurds vary from three to four million (Celik 2005: 140; Gunter 2004). In our survey, 23 per cent of those who migrated report the reason for their migration as security and forced migration.

20 The vast majority of Turks follow the Hanefi school ( 93 per cent), while the majority of Kurds follow Shafi teachings (about 60 per cent). Some Kurds do subscribe to the Hanefi school (about 35 per cent), but we do not see many Shafi Turks (only 2.3 per cent).

\section{References}

Aslan, A. H. 2012. 'Does the Gulen movement securitize the Kurdish question?', Today's Zaman, 2 March. http://www.todayszaman.com/columnists/ali-h-aslan_273084-does-thegulen-movement-securitize-the-kurdish-question.html. Accessed on 7 September 2012.

Ataman, M. 2003. 'Islamic perspective on ethnicity and nationalism: diversity or uniformity?', Journal of Muslim Minority Affairs 23, 1: 89-102.

Aydınl, E. 2002. 'Between security and liberalization: decoding Turkey's struggle with the PKK', Security Dialogue 33, 2: 209-25.

Barkey, H. J. 1998. 'The People's Democracy Party (HADEP): the travails of a legal Kurdish party in Turkey', Journal of Muslim Minority Affairs 18, 1: 129-38.

Barkey, H. J. and Fuller, G. E. 1998. Turkey's Kurdish Question. New York: Rowman and Littlefield Publishers, Inc.

Bozarslan, H. 1996. 'Turkey's elections and the Kurds', Middle East Report 199: 16-9.

Bozarslan, H. 2001. 'Human rights and the Kurdish issue in Turkey', Human Rights Review 3, 1 : $45-54$.

Bruinessen, M. V. 1992. Agha, Shaikh and State: The Social and Political Structures of Kurdistan. London and Atlantic Highlands, NJ: Zed Books.

Bruinessen, M. V. 2000. Mullahs, Sufis and Heretics: The Role of Religion in Kurdish Society: Collected Articles. Istanbul: Isis Press.

Carkoglu, A. 2005. 'Political preferences of the Turkish electorate: reflections of an alevi-sunni cleavage', Turkish Studies 6, 2: 273-92.

Carkoglu, A. and Kalaycioglu, E. 2009. The Rising Tide of Conservatism. New York: PalgraveMacmillan.

Casier, M. and Jongerden, J. (eds.) 2011. Nationalisms and Politics in Turkey: Political Islam, Kemalism and the Kurdish Issue. New York: Routledge.

Celik, A. B. 2005. 'I miss my village!: Forced Kurdish migrants in Istanbul and their representation in associations', New Perspectives on Turkey 32: 137-63.

Cizre, U. 1998. 'Kurdish nationalism from an Islamist perspective: the discourse of Turkish Islamist writers', Journal of Muslim Minority Affairs 18, 1: 73-90.

Connor, W. 1994. Ethnonationalism: The Quest for Understanding. Princeton: Princeton University Press. 
Conversi, D. 2000. The Basques, the Catalans and Spain: Alternative Routes to Nationalist Mobilization. London: Hurst and Company.

Cornell, S. E. 2001. 'The Kurdish question in Turkish politics', Orbis 45, 1: 31-46.

Duran, B. 1998. 'Approaching the Kurdish question via "Adil Düzen": an Islamist formula of the welfare party for ethnic coexistence', Journal of Muslim Minority Affairs 18, 1: 11129.

Ekmekci, F. 2011. 'Understanding Kurdish ethnonationalism in Turkey: socio-economy, religion and politics', Ethnic and Racial Studies 34, 9: 1608-17.

Entessar, N. 1992. Kurdish Ethnonationalism. Boulder and London: Lynne Rienner Publishers.

Ergil, D. 2000. 'The Kurdish question in Turkey', Journal of Democracy 11, 3: 122-35.

Ergin, S. 2000. 'Güneydoğu için hükümetten beklenen', Milliyet 22 September.

Gunes-Ayata, A. and Ayata, S. 2002. 'Ethnic and Religious Bases of Voting' in S. Sayari, Y. Esmer (eds.), Politics, Parties, Elections in Turkey. London: Lynne Rienner Publishers.

Gunter, M. M. 1990. The Kurds in Turkey: A Political Dilemma. Boulder, San Francisco and Oxford: Westview Press.

Gunter, M. M. 1997. The Kurds and the Future of Turkey. New York: Sn. Martin's Press.

Gunter, M. M. 2004. 'The Kurdish question in perspective', World Affairs 166, 4: 197205.

Gurr, T. R. 1970. Why Men Rebel. Princeton: Princeton University Press.

Gurr, T. R. 1993. 'Why minorities rebel: a global analysis of communal mobilization and conflict since 1945', International Political Science Review 14, 2: 161-201.

Hale, H. E. 2000. 'The parade of sovereignties: testing theories of secession in the society setting', British Journal of Political Science 30, 1: 31-56.

Hechter, M. 1975. Internal Colonialism. The Celtic Fringe in British National Development 1536-1966. Berkeley, CA: University of California Press.

Heper, M. 2007. The State and Kurds in Turkey: The Question of Assimilation. New York: Palgrave Macmillan.

Horowitz, D. L. 1985. Ethnic Groups in Conflict. Los Angeles, CA: University of California Press.

Houston, C. 1999. 'Civilizing Islam, Islamist Civilizing? Turkey's Islamist Movement and the problem of ethnic difference', Thesis Eleven 58, 1: 83-98.

Houston, C. 2001. Islam, Kurds and the Turkish Nation State. Oxford, New York: Berg.

Icduygu, A. et al. 1999. 'The ethnic question in an environment of insecurity: the Kurds in Turkey', Ethnic and Racial Studies 22, 6: 991-1010.

Jongerden, J. and Akkaya, A. H. 2011. 'Born from the left: the making of the PKK' in M. Casier, J. Jongerden (eds.), Nationalisms and Politics in Turkey: Political Islam, Kemalism, and the Kurdish Issue. New York: Routledge.

Jwaideh, W. 2006. Kurdish National Movement: Its Origins and Development. New York: Syracuse University Press.

Kirişç, K. and Winrow, G. M. 1997. The Kurdish Question and Turkey: An Example of Trans-state Ethic Conflict. Portland: Frank Cass.

Kocher, M. 2002. 'The decline of PKK and the viability of a one-state solution in Turkey', International Journal on Multicultural Societies 4, 1: 128-47.

Lecours, A. 2000. 'Ethnonationalism in the West: A Theoretical Exploration.' Nationalism \& Ethnic Politics 6(1): 103-124.

Loizides, N. G. 2010. 'State ideology and the Kurds in Turkey', Middle Eastern Studies 46, 4: $513-27$.

Long, S. J. 1997. Regression Models for Categorical and Limited Dependent Variables. Thousand Oaks: Sage Publications.

McDowall, D. 1996. A Modern History of the Kurds. London: I.B. Tauris.

McGarry, J. 1995. 'Explaining ethnonationalism: the flaws in western thinking', Nationalism and Ethnic Politics 1, 4: 121-42.

Menard, S. 2002. Applied Logistic Regression Analysis. Thousand Oaks: Sage Publications. 
Mitchell, G. 2012. 'Islam as peacemaker: the AKP's attempt at a Kurdish resolution', The Washington Review of Turkish and Eurasian Affairs. 7 May 2012. http://www .thewashingtonreview.org/articles/islam-as-peacemaker-the-akps-vision-of-a-kurdishresolution.html. Accessed on 27 August 2012.

Olson, R. (ed.) 1996. The Kurdish Nationalist Movement in the 1990s: Its Impact on Turkey and The Middle East. Kentucky: The University of Kentucky Press.

Ozkirimli, U. 2013. 'Vigilance and apprehension: multiculturalism, democracy and the "Kurdish Question" in Turkey', Middle East Critique. 22, 1: 25-43.

Romano, D. 2006. The Kurdish Nationalist Movement: Opportunity, Mobilization and Identity. Cambridge, UK: Cambridge University Press.

Rothschild, J. 1981. Ethnopolitics: A Conceptual Framework. New York: Columbia University Press.

Saatci, M. 2002. 'Nation-states and ethnic boundaries: modern Turkish identity and TurkishKurdish conflict', Nations and Nationalism 8, 4: 549-64.

Sarigil, Z. 2009. 'Paths are what actors make of them', Critical Policy Studies 3, 1: 121-40.

Sarigil, Z. 2010. 'Curbing Kurdish ethnonationalism in Turkey: an empirical assessment of pro-Islamic and socio-economic approaches', Ethnic and Racial Studies 33, 3: 533-53.

Smith, T. W. 2005. 'Civic nationalism and ethnocultural justice in Turkey', Human Rights Quarterly 27, 2: 436-70.

Somer, M. 2005. 'Resurgence and remaking of identity: civil beliefs, domestic and external dynamics and the Turkish mainstream discourse on Kurds', Comparative Political Studies 38, 6: $591-622$.

Sorens, J. 2005. 'The cross-sectional determinants of secessionism in advanced democracies', Comparative Political Studies 38, 3: 304-26.

Tezcur, G. M. 2009. 'Kurdish nationalism and identity in Turkey: a conceptual reinterpretation', European Journal of Turkish Studies 10: 1-5.

Tezcur, G. M. 2010. 'When democratization radicalizes: the Kurdish nationalist movement in Turkey', Journal of Peace Research 47, 6: 775-89.

Watts, N. F. 1999. 'Allies and enemies: pro-Kurdish parties in Turkish politics, 1990-94', International Journal of Middle East Studies 31, 4: 631-56.

White, P. J. 1998. 'Economic marginalization of Turkey's Kurds: the failed promise of modernization and reform', Journal of Muslim Minority Affairs 18, 1: 139-58.

White, P. J. 2000. Primitive Rebels or Revolutionary Modernizers? The Kurdish National Movement in Turkey. London/New York: Zed Books.

Yavuz, M. H. 1998. 'A preamble to the Kurdish question: the politics of Kurdish identity', Journal of Muslim Minority Affairs 18, 1: 9-18.

Yavuz, M. H. 2001. 'Five stages of the construction of Kurdish nationalism in Turkey', Nationalism and Ethnic Politics 7, 3: 1-24.

Yavuz, M. H. and Ozcan, N. A. 2006. 'The Kurdish question and Turkey's justice and development party', Middle East Policy 13, 1: 102-19.

Yegen, M. 1996. 'The Turkish State discourse and the exclusion of Kurdish identity', Middle Eastern Studies 32, 2: 216-29.

Yegen, M. 2007. 'Turkish nationalism and the Kurdish question', Ethnic and Racial Studies 30, 1: $119-51$.

Yegen, M. 2011. 'The Kurdish question in Turkey: denial to recognition' in M. Casier, J. Jongerden (eds.), Nationalisms and Politics in Turkey: Political Islam, Kemalism, and the Kurdish Issue. New York: Routledge.

Yildiz, C. 2012. 'Gülen'den Kürt sorununa çözüm önerisi: Bağırıp çağırarak olmaz', Radikal, 9 September 2012. http://www.radikal.com.tr/Radikal.aspx?aType=RadikalDetayV3\&ArticleID $=1099733 \&$ CategoryID=77. Accessed on 11 September 2012 . 


\section{Appendix A: Descriptive statistics}

\begin{tabular}{lrrrrr}
\hline \hline Variable & $N$ & Mean & Std. Dev. & Min & Max \\
\hline Dependent & & & & & \\
$\quad$ Cultural ethnonationalism (index) & 863 & 6.90 & 1.41 & 4 & 8 \\
$\quad$ Political ethnonationalism (index) & 855 & 5.68 & 1.61 & 4 & 8 \\
Independent & & & & & \\
$\quad$ Household income (logged) & 812 & 2.97 & 0.24 & 2 & 4 \\
Education & 898 & 3.44 & 1.49 & 1 & 7 \\
Discrimination perception & 892 & 1.46 & 0.49 & 1 & 2 \\
Religiosity index (practice) & 880 & 3.41 & 0.75 & 2 & 4 \\
Religiosity index (attitude) & 880 & 3.76 & 0.60 & 2 & 4 \\
Ideology (left-right placement) & 847 & 2.95 & 0.93 & 1 & 5 \\
Residence (rural-urban) & 901 & 1.83 & 0.78 & 1 & 3 \\
Region (southeast) & 901 & 0.33 & 0.47 & 0 & 1 \\
Unemployment & 898 & 0.10 & 0.30 & 0 & 1 \\
Religious sect (Shafi) & 872 & 0.57 & 0.49 & 0 & 1 \\
Gender & 901 & 1.51 & 0.50 & 1 & 2 \\
Age & 901 & 36.61 & 13.50 & 18 & 86 \\
\hline \hline
\end{tabular}




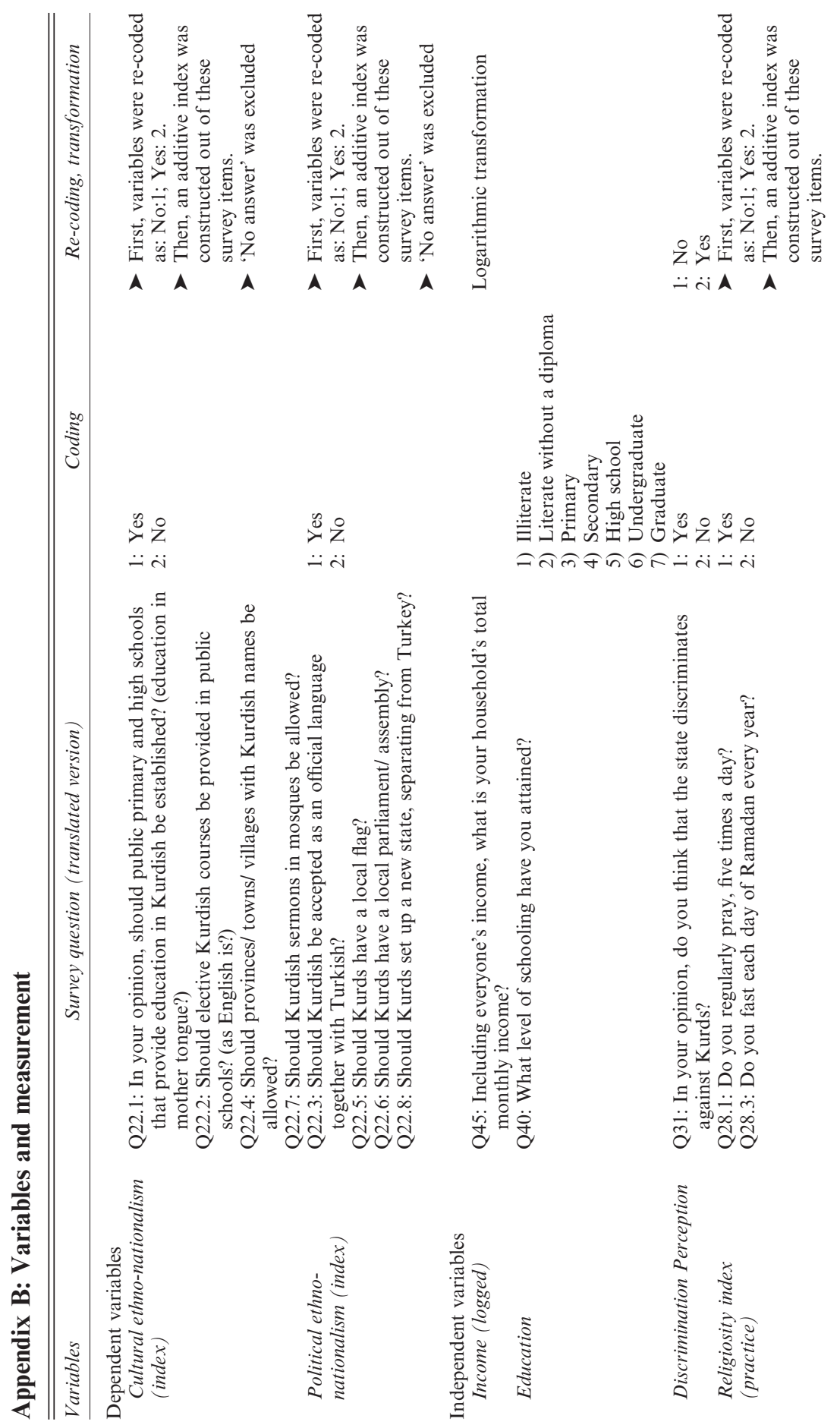

(C) The author(s) 2014. Nations and Nationalism (C) ASEN/John Wiley \& Sons Ltd 2014 


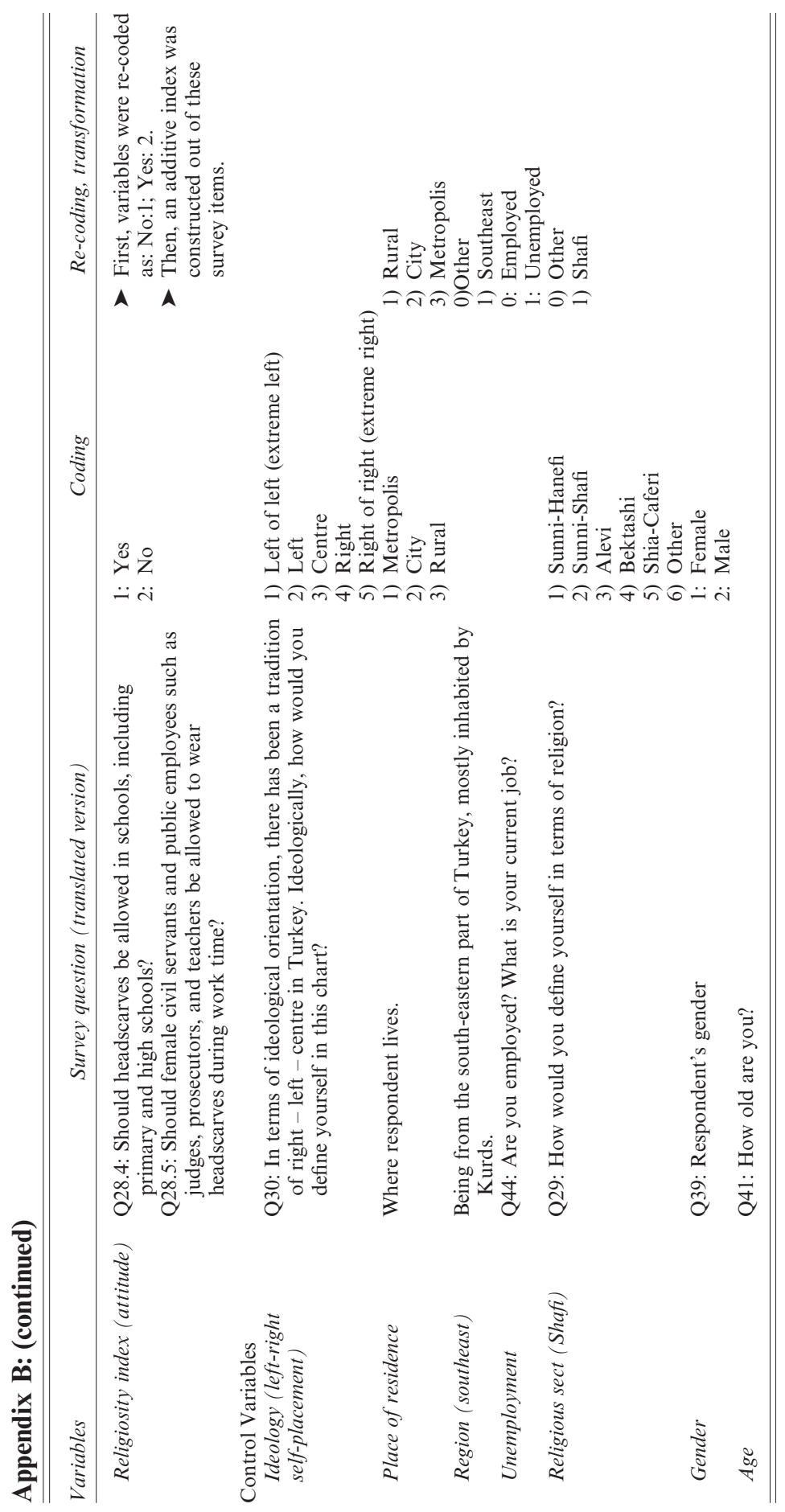

